\title{
The influence of Austrian voting right of 1907 on the first electoral law of the successor states (Poland, Romania [Bukovina], Czechoslovakia)
}

\author{
Dr Andrzej Dubicki \\ Uniwersytet Łódzki
}

\begin{abstract}
As a result of collapse of the Central Powers in 1918 in Central Europe have emerged new national states e.g. Poland, Czechoslowakia, Hungaria, SHS Kingdom some of states that have existed before the Great War have changed their boundaries e.g. Romania, Bulgaria. But what is most important newly created states have a need to create their constituencies, so they needed a electoral law. There is a question in what manner they have used the solutions that have been used before the war in the elections held to the respective Parliaments (mostly to the Austrian or Hungarian parliament) and in case of Poland to the Tzarist Duma or Prussian and German Parliament. In the paper author will try to compare Electoral Laws that were used in Poland Czechoslowakia, and Romania [Bukowina]. The first object will be connected with the question in what matter the Austrian electoral law have inspired the solutions used in respective countries after the Great War. The second object will be connected with showing similarities between electoral law used in so called opening elections held mainly in 1919 in Austria-Hungary successor states. The third and final question will be connected with development of the electoral rules in respective countries and with explaining the reasons for such changes and its influence on the party system in respective country: multiparty in Czechoslovakia, hybrid in Romania.
\end{abstract}

Keywords: Poland, Romania, Czechoslovakia, Electoral law, politics.

In the countries that emerged in 1918 after the collapse of the Austro-Hungarian Empire, also known as the successor states, all political principles had to be built from scratch. On the one hand, it was a unique opportunity to try new political solutions.

On the other hand, using commonly known rules might be considered useful in stabilizing the country, since the elections, one of the key elements of democracy, could be held according to widely accepted principles that were attributed to the former political system, which helped to raise the trust of the new country's citizens.

The article aims to trace the main regulations of Austrian electoral law of Imperial Council in 1907 and find their influence on first electoral law in the successor states (Romania [Bukovina], Czechoslovakia) and Poland.

The starting point of the research is the Austrian law governing the elections to Imperial Council in its final version of 1907, when in the effect of the so-called Beck's electoral reform, general and equal voting right was introduced in Austria.

The tradition of general elections in the Austrian Empire itself was formed in 1896 (due to Badeni reform), when to the previously existing four classes of voters, formed on the financial possibilities, a fifth class was added, with every citizen with voting right being able to make his choice.

Apart from the issue of generality, the reform in question introduced the idea of unequal voting and plural voting. It was possible due to granting voting right to the members of the fifth class, and also those who were allowed to vote in classes I-IV, which made it possible for them to vote twice (Starzyński, 1907, p. 75). It should be mentioned that in the end of the 19th century Austrian electoral law was not extraordinary. Plural voting existed in other countries, in Belgium on the country level and in Sweden - on the local level.1.

New electoral law, introduced in the Austrian Empire in 1907, meant serious changes in the basic rules of voting, since it replaced the former rule of political representation typical of class voting with the principle of citizen representation.

The additional aim of the new law was to reconcile different nations of the Austro-Hungarian Empire by granting mandates to particular nations living in precise electoral districts. It was clearly visible in the region of Moravia, where it was possible to set electoral districts in such a way that mandates would be given to particular peoples (Starzyński, 1907a, p. 289), thanks to the 1905 national cadastre.

1 It should be mentioned that in the end of the 19th century Austrian electoral law was not extraordinary. Plural voting existed in other countries, in Belgium on the country level and in Sweden - on the local level. 
It is worth mentioning that the idea of introducing similar changes in other parts of the Empire, Galicia included, were facing strong opposition of the local politicians, especially in regions inhabited by mixed nationalities. In other parts of Austria of the time, similar division was meant to be introduced in a more subtle way (Buszko, 1956, p. 30-31), but with a superior idea of a balance between Slavic and Germanic-Romanic element (Starzyński, 1907a, p. 290).

An element meant to regulate political life in Austria was introducing a partial reform of the House of Lords (Higher House of the Parliament). It involved setting a definite maximal number of its members appointed by the Emperor to 150-170, which disabled halting virtually every new statute drawn by the Lower House of the Parliament by appointing numerous members.

The outcome was dubious, since it also made it difficult to have a majority in voting a new project over. The second element of the reform was to allow hereditary peers of the House of Lords to run in the elections to the House of Representatives, on condition that their membership would be suspended while belonging to Imperial Council.

An important novum introduced by electoral law of 1907 was the possibility of direct vote for all the voters. Such opportunity had been possible earlier only in classes I-III, in lower classes it was only one of many options. It used to be a common situation in Europe, for instance in Romania, so Austria was not archaic in that sense.

A curious fact in Austria was that passive voting right was slightly broader than active. in this particular case there did not exist domicile status, which was obligatory in case of active voting right and set to last one year, the obligation of one year permanent residence in a certain electoral district was a result of a compromise. The Left wanted to remove this entry from electoral law as designed against workers who used to migrate in search of work, whereas Christian Democracy postulated obligatory residence of 3 to 5 years, which was to support the settled (Starzyński, 1907a, p. 293).

Another novum put forward by Beck's law was an introduction of single- member districts, with the possibility of existence of double-member districts in the areas ethnically non-homogenous, where the second mandate was meant for a person belonging to an ethnic minority group. It was practiced only in Galicia (Starzyński, 1907a, p. 434)1, where in the areas dominated by the Ukrainians, it was used to help Polish representatives in being granted a mandate (J. Buszko, 1956, p. 78).

This new law secured the interests of the ethnic minority groups, by granting the representative of such group the opportunity to enter Imperial Court on condition that he was supported by at least $25 \%$ of the voters of his electoral district. It was a novelty in Austrian solutions.

It should be mentioned that this way of choosing a minority MP was faced with considerable restrictions. One of them was the necessity to acquire at least $50 \%$ of votes by the representative of the majority, and in case of not gaining such number of votes by a candidate from a district in question, the voting procedure had to be repeated, no matter whether the threshold of $25 \%$ had been passed or not (Starzyński, 1907a, p. 299).

The voting was based on the principle of a single non-transferable vote (SNTV), used then in Brasil on provincial and municipal levels (Starzyński, 1907a, p. 300). The procedure of granting seats in the Parliament itself was obviously based on the plurality voting system, with the use of ballot which took place one week after the first voting. Only two candidates who acquired the majority of votes in the first voting ran in it. As previously mentioned, it took place almost everywhere in Austria, except 36 country districts. The rules in those districts were more complicated, and in extreme cases as many as 4 dates of voting were needed to choose two MPs, but this could only happen when the majority candidate was the only person who got votes, which was hardly possible.

Nevertheless, using the voting procedure in question with proper division of rights and high political awareness of the majority of voters, it was possible to choose two majority candidates in one electoral district. There was no solution to such behaviour of the majority, despite the existence of other aspects of voting, especially its sectreteness (Starzyński, 1907a, p. 443)2.

Due to the introduction of the minority MP, the institution of substitute MP was also introduced. He was appointed when the elected MP was not able to fulfil his duties. Every MP had his substitute MP appointed3. in case of majority voting, additional

170 electoral districts were established there: 34 single-member town districts and 36 double-member country districts.

2 in Moravia there was such a possibility, but it involved signing the voting papers. When a particular MP was discharged from a local parliament in a district, his substitution MP was chosen only by those who voted for the MP in question. It involved an infringement of the idea of secret ballot and keeping voting papers during the whole tenure.

3 This voting method can be compared to the American way of voting for president as it was formed after 1804 , when it was possible to point a particular common candidate for president, and different candidates for vice-presidents. 
voting is much more common to the institution of substitution MP. It was not possible, however, if having in mind that minority groups were supposed to be represented as well, since it would violate the rule of general elections (only the minority group in a particular electoral district would vote) or the rule of secret ballot (voting cards would have to be signed or every vote should be recorded on the voting lists).

Substitute MPs were chosen in voting similar to voting for MPs, with the restriction that the choice would only be valid on condition that the MP whom the substitute was to represent, would be chosen as well. in case of runoff voting, a second voting for the substitute MPs was usually arranged as well. in case of death of a substitute MP during the tenure, whether he was a member of the House or not, his mandate was considered vacant.

An important new element introduced in 1907 was a strict definition of the date of mandate verification by the House itself, which had not had any regulations earlier. It sometimes happened that no statue at all was introduced because of that. Due to new regulations, it was meant to happen during the first year of the House tenure, which was a very liberal attitude anyway, since in the same period in other countries, for instance in Romania, the mandate verification was done even before the first meeting (Dubicki, 2013, p. 98).

Class system was eliminated, which, together with making it easier for a man to vote, strengthened the idea of general voting. The way to give a vote was much easier since the polling places were set locally, not on county levels. The only exception was again Galicia, where national authority allowed the areas having less than 1200 citizens to organize common voting. The only condition was that there should not be more than 5000 people voting together.

The regulations in question were probably introduced to lower the costs of voting. The group of offences because of which the citizens were deprived of the right to vote was enlarged. Some of them were common crimes, like for instance, drunkenness.

A characteristic feature of the new law was the introduction of compulsory voting on the country level, which meant that all the parts of Austria had the right to decide upon its potential introduction and decide on their own how to carry it out (Starzyński, 1907a, p. 230). The autonomy of the voting right was linked to the features of particular regions, especially in mountain areas where the citizens used to travel together with their herds to the fields and used to stay there for as long as six months, so it was scarcely possible for them to fulfill their voting duty. Until 1907 voting duty was introduced in: Lower Austria, Upper Austria, Moravia, Silesia, Salzburg and Vorarlberg. It was meant to be introduced in Tyrol and Bucovina as well, whereas in Bohemia this matter was not solved in 1907 (Starzyński, 1907a, p. 236). The fine for the absence at the voting was from 1 to 50 krones and it could not been changed for imprisonment. The only possible punishment was a fine.

In Galicia as well, in the elections to The Diet of the Kingdom of Galicia and Lodomeria, the rule of proportional counting of votes was tried to be introduced; in the heated debate before the introduction of general voting right in Galicia there appeared some ideas of common voting right by Stanisław Głąbiński and Józef Buzek.

When speaking about contemporary voting right and its features compared to world regulations, Buzek's project is important because it was the first moment when the idea of proportionality and choosing a particular candidate, so using open lists during proportional voting, were introduced (Starzyński, 1907a, p. 219).

From the point of view of subsequent practice, the method suggested by Buzek had been important, since the author was one of the key authors of new electoral law of The Second Polish Republic (Buzek, 1922)1.

\section{Electoral law valid in Romanian Bucovina in the period 1919-1926}

After the end of World War I and the collapse of the Austro-Hungarian Empire, the territory of Bukovina was located within Romanian borders. Due to this fact, it became necessary to organise a separate electoral law for Bukovina. It was in accordance with the rule, approved in the whole country, of holding elections on the basis of various electoral laws. The rule was unique, as far as Europe was concerned. Separate solutions were organized for particular parts of the country, which belonged to different states before WWI. Romanian Old Kingdom, Bessarabia, Transylvania and Bukovina were using different solutions, whose one shared feature was the electoral law of 16 November 1918. Its main idea was the introduction of general voting, and a proportional system of counting voices, however, these were very general guidelines, eventually introduced in the whole country not before 1926, with another electoral law coming into effect.

1 His main ideas concerning electoral law between the wars were presented in the book: J. Buzek, Ordynacja wyborcza do Sejmu i

Senatu, Warszawa-Lwów, 1922. 
An electoral law for Bukovina territory was constructed on the basis of the nationwide law. Here, in accordance with the 26 August 1919 act, elections were supposed to be: general, equal, direct and secret. The rule of compulsoriness was not forgotten either. Here, plurality voting system was supposed to be used, and a senator and an MP were to be chosen in each election district. Three MPs were to be chosen only in Cernauti, according to the proportionality principle. Thus, it was a mixed voting system. in Bukovina, 26 MPs were to be elected in general election (23 in single-member districts and 3 in a multi-member district), together with 12 senators (Mamina, 2000, p. 61)1. Those who committed hostile acts against the state or the Romanian nation would also join the group of people deprived of voting rights. Those who did not accept being naturalised or who renounced Romanian citizenship, those who did not swear an oath to be loyal to Romania and people with no political rights, were also deprived of voting rights. When it comes to these people, a solution, inspired by the Austrian model, was making it impossible to vote for people who were under the surveillance of the police (Radu, 2005, p. 165). The Acquisition of some solutions that had been successful before, in the period of Austria-Hungary, could be seen here. The introduction of single-member districts (23) in the country was most undoubtedly caused by the will to maximise the amount of mandates for the Romanian MPs and senators.

The organisation of elections was supposed to be slightly different than in Romanian Old Kingdom; here one central election committee was to be created and perform all the necessary election procedures. The voting procedure itself was supposed to be slightly different here as well. Every electoral register should be printed on paper of a different colour. The unwanted lists were supposed to be left in a ballot box which was to be found in the voting booth, while the list chosen by the elector was to be placed in an envelope and handed in to the chairman of the election committee, who would place it in the proper ballot box. The voting certificate would be stamped and returned to the elector in case of subsequent runoff voting. It was important, because in Bukovina in case none of the candidates reached absolute majority of voices $(50 \%+1)$, another round had to be run, between the candidates with most voices. This was an idea taken from the Austrian electoral law. If it turned out that both candidates were awarded the same number of voices in the second round, assigning mandates would be performed using lottery-drawing. in case of Cernauți, the same as in Romanian Old Kingdom, the mandates belonging to municipalities in the election to the Lower House, were supposed to be split according to d'Hondt method (Radu, 2005, p. 165).

The abovementioned regulations were upheld in Bukovina until 1926, when a nationwide unified electoral law was introduced, in which none of the solutions adopted from the former Austrian law were used.

\section{Czechoslovakia and its electoral law}

In the newly established Czechoslovakian country, legislative authority was given to a two-chamber National Assembly, consisting of Chamber of Deputies and Senate. The right to candidate, in case of Chamber of Deputies, was given to every person who was at least 30 years old, and every 21-year-old, or older, person was entitled to suffrage. in case of Senate, these numbers were higher, respectively: 45 in case of the right to candidate, and 26 in case of suffrage (Starzyński, 2010, p. 165, 166).

Electoral law was described as consisting of 6 adjectives, which means that the "standard" equal, proportional, free, secret and general became accompanied by compulsory. Voting was compulsory under penalty of fine or jail. This idea was quite common back then and it was adopted into the Czechoslovakian electoral law from Belgium (Starzyński, 2010, p. 165)2. Every electoral register had to be supported by 100 electors. It was prohibited to candidate in several districts simultaneously, as well as to run for MP and senator at the same time. The latter restriction was practically applied when elections to both chambers took place at the same time. Should they take place at different times, an MP could run for senator, and vice versa. According to legislators, such possibility would occur relatively infrequently, as the Czechoslovakian voting system was characterized by extremely long tenures - Chamber of Deputies was supposed to be chosen every 6 years, Senate every 8 years. Thus, it is easy to count that, apart from the first election, which had not taken place until 1920 (Bohemia and Slovakia) and 1924 (Carpathian Ruthenia), the first mutual election would take place after 24 years, in 1944, theoretically. However, due to the shortening of both chambers' tenures, the elections were mutually held in: 1920 (Chamber of Deputies election on 18 April 1920; Senate election on 25 April 1920); 1925 (15 November); 1929 (27 October); 1935 (19 May).

1 Bukovina was granted a certain number of seats in the Senate, being given after appointment.

2 Imprisonment was a new penalty for absence during voting in Czechoslovakia, since earlier the Austrian regulations had been using fine only. 
Allocating seats after the election proceeded as follows: an electoral quotient was established, which later helped to allocate particular seats for an adequate party. in case one list was allocated more seats than candidates on electoral registers, the vacant seats would be transferred to the countrywide pot, divided by the central election commission 8 days after the election. in this second deal, the entire country became one election district. in that case, only people who run for mandate in general election could candidate. What is more, only the parties which obtained at least one seat before had the right stand for this deal. This procedure was justified by the fact that only a person who had been verified to a certain degree during the election could be chosen1. This time, the election committee worked out another electoral quotient, taking into consideration the remaining voices across the country, the ones which were not used when allocating seats. They were used to calculate a number of mandates to be allocated in round two. in case the number of MPs did not reach 300 , yet another, third, round of allocating seats took place.

Czechoslovakian Senate consisted of 150 senators, it was appointed for 8 years, as it has been mentioned earlier, but no term of office lasted that long. The longest tenure was in the years 1929-1935, when the Chamber of Deputies managed to hold, in other cases the tenure was shortened. This fact may lead to two ideas.

First of all, the myth of endurance and stability of Czechoslovakian democracy has to be revised, since only one Parliament (or rather its half) during the interwar period managed to work during its entire term of office (Tomaszewski, 2006)2. Romania had higher rates, since there were two full terms of office completed (1922-1926, 1933-1937) (Dubicki 2013, p. 439).

Another matter to consider is the influence of the length of the tenure on the stability of the Parliament. It is clearly visible that the idea that was supposed to stabilize the rule, worked the opposite. in case of Czechoslovakia, it can be said that the fight to stabilize political situation with the use of "five" had measurable benefits that could trigger dissatisfaction of the citizens, especially in Slovakia.

It can be even concluded that constant presence of the same politicians in the circle made Czechoslovakia resemble a type of democracy in which the citizens were able to control only the highest authorities, which made it almost impossible to change them. in case of any social or ethnic tension, the electorate might get discouraged from being interested in politics, or even express their social discontent, which eventually led Czechoslovakia to disintegrate.

In case of the Higher House of Czechoslovakian Parliament there existed a possibility of office workers standing for elections. During the tenure they were on a leave from their office. It was forbidden to combine the MP mandate with the membership of local assembly, Constitutional Tribunal or Electoral Tribunal. It was also forbidden to be both an MP and a Senator.

It was possible to take away the mandate from a person who was excluded from a party because of "low reasons" or dishonest behaviour, which was meant to stabilise the rule of the authorities. Another way of losing a mandate was after being taken away civil rights because of a court judgement. S. Starzyński considered that solution a judicial protection of party loyalty (Starzyński, 2010).

Sessions of the Parliament were held twice a year: during spring time (in March) and fall time (in October). Those were obligatory Parliament meeting times, but the President could ask the Parliament to meet on a special session, on his will or when suggested by one of the Houses. in that case, the range of issues raised during the debate had to be given. There was also a rule ordering the Houses to meet not later than 4 months after the last session.

Both Houses used closed list voting, which was modelled on German law. To count the votes during the first voting round, Hare quota formula was used on the state level (Buzek, 1922)3. Using this method of counting votes resulted in only a part of the mandates being allocated during the first round of voting 4 .

During the next rounds, the lists could be suggested only after the elections, but the order according to which the candidates appeared on voting lists did not necessarily have to use their former result. in the next round, Hagenbach-Bischoff's quota

\footnotetext{
1 in similar circumstances, there appeared an accusation of creating a possibility of allocating seats taking into account people who did not take part in the elections during a debate on a reform of electoral law in Romania in 2008.

2 Despite its polarisation, Czechoslovakian Parliament used to function in a proper way due to the creation of not formal and outside Parliamentary forum, called pětka (the five), which took care of keeping the authority majority for Jan Černy's cabinet. Since this solution worked well, later it was practiced as well. From 1926 the fraction gathered 8 most prominent politicians of the state.

3 Precise rules connected with distributing mandates in Czech see: J. Buzek, op. cit., s. 50.

4 in smaller electoral districts even half of the mandates were not fulfilled
} 
(Starzyński 2010) was used. in the third round, mandates were distributed to particular political parties according to the result of the second voting round, until there was no free seat.

More serious changes were made in 1925, when next elections took place. This time electoral law was adjusted to new administrative division of the country (the division into 20 zhupas). The number of candidates on the voting lists was limited to the number of mandates to be distributed in a particular electoral district and the right to take part in the second round of mandate distribution was only given to those parties who received at least one mandate in general elections.

The procedure of the distribution of votes in the second round was changed as well. This time the number of unused votes was divided according to Hare quota from the first round. The rules of distributing votes in the third round were changed in a similar way as well, ethnic minorities and the parties whose members had already got mandates during the second round of voting being preferred.

Next amendments were introduced in 1927 and 1935. in 1927 military men in service were effused voting right according to the rules valid in the neighbouring countries' legislation. in 1935 the method of voting distribution in the second round was being manipulated again.

Only those parties who acquired at least 20000 votes (or 35000 when it comes to the Senate) in one electoral district, or 120000 votes on the country level, were allowed to take part in the second round of elections. Generally, the electoral law in Slovakia during the I Republic involved the use of close lists, Hare quota and Hagenbach-Bishoff quota. There was no threshold, but using the two methods mentioned above, it was not necessary.

The system that resulted from it can be classified as multiparty in which different political parties were considered relevant and possessing strong coalition value. That can be said about almost all political parties except The Communist Party of Czechoslovakia and the party of the Sudeten Germans. Thus, according to Sartori, this can be called a multiparty polarised system. The classification is justified by the presence of strong opposition, not able to come to agreement (there was no possibility of the communists coming to terms with the Sudeten Germans).

The formation of multiparty polarized system meant the existence of many political parties, and the lack of threshold enabled many political parties, whose exact number is not possible to estimate due to many changes in the near-electoral period, to enter the Parliament.

An additional political matter was the fact that in the first period of the existence of the country, the main distinguishing factor was not ideology, but ethnic belonging, which made Czechoslovakia similar to The Kingdom SHS.

The President was entitled to dissolve the Parliament in general, or one House only, but he was not allowed to do so during the last 6 months of his presidential term of office.

What is important, even though the Constitution mentioned free mandate, it was rather imperative mandate that was present in Czechoslovakia. Parliamentary mandate was treated as belonging to a particular political party. To assure an MP's loyalty, the party usually threatened him not only to move him out of any of the parliamentary Houses, but also to make use of the promissory notes he had been made to sign before the elections. It was such common a practice that sometimes in the commentaries on Czechoslovakian political system there appeared voices that it cannot be considered to be a state with the existence of free mandate (Starzyński, 2010, p. 167).

It can be attributed to the fact that during the first elections in Czechoslovakia in 1919, the Parliament was chosen due to a deal: the political parties who in great majority had existed before the war, got the right to represent the state politically on the basis of the voting results from 1911. They received an appropriate number of mandates, but the exact personal decisions were left to political parties to make (Tomaszewski, 2005, p. 35).

The division into electoral districts was not equal. The number of citizens living permanently in a particular electoral district was taken into consideration. The electoral district of Prague was the biggest, with $45 \mathrm{MP}$ mandates to be distributed and Liptovsky Mikulas- the smallest, with only 6 mandates. They were still very big electoral districts, with ethnic minority groups and small political fractions being favoured.

It was beneficial for the Czechs, especially in the Sudetes and in electoral districts in Cieszyn Silesia, where they were not a visible majority. The density of population being taken into consideration, most of the mandates were given to Czech, where $157 \mathrm{MPs}$, so the majority of the House, were chosen. in Moravia $63 \mathrm{MPs}$ were chosen and in Slovakia 61. ${ }^{1}$

1 It should be reminded that in Carpathian Ruthenia elections were not held until 1924, when 18 MPs were chosen. 


\section{The solutions introduced by so-called Moraczewski Electoral Law in Poland}

In Poland, reborn in 1918, after 123 years, a need to conduct parliamentary elections was soon expressed, which triggered the appearance of the first electoral law very quickly, as early as in November 28,1918 , almost simultaneously with the document setting the date of elections for January 26, 1919. in Poland the situation differed from the one in Czechoslovakia, where first elections took place in 1920 and in Romania- in November 1919, since the elections immediately followed the proclamation of new electoral law.

Such rapid legislative process can be attributed to the postulate of the Head of State, Józef Piłsudski, to conduct the elections as soon as possible to legitimise the right to rule of the new authorities. According to Piłsudski's memoirs, it was drafted by Jędrzej Moraczewski's government in 10 days (Watt 2005, p. 21).

In theory, the elections were to be held according to the rule of the five adjectives. Belgian regulations, with a small modification enabling the creation of so-called electoral blocks (Buzek, 1922, p. 31) to make it possible to count together the voices given to forces belonging to them, were being looked up to. According to J. Buzek, such action had not been thought over, since it made it easier for smaller parties to get a mandate, which introduced even greater element of insecurity to elections and it broke the idea suggested by d'Hondt method, which is known to promote bigger political parties (Buzek, 1922, p. 36)1.

The right to candidate and the right to suffrage was limited with a relatively law age qualification - 21 years (Buzek, 1922, p. 22). What was new, was granting the voting right to women. When it comes to the voting formula - d'Hondt method was used in plural mandates electoral districts that differed from each other in terms of the number of seats to take. in the biggest district, the district of Warsaw, 16 mandates were ready to be taken, the smallest electoral districts (with only 3 seats) were in Cieszyn Silesia.

In general, there was a rule that was used later as well, linking the number of seats in a particular electoral district with the number of citizens living there - the proportion was estimated as 1: 50000.

Overall, the estimated number of MPs was 513 but finally there were 442 deputies, but only 364 of them were elected, the rest (78) were appointed.

That electoral law was heavily criticised just from the beginning. Right-wing andagrarian fractions put forward their doubts claiming that it was an element of socialists' dictate, not including their demands. What is more, especially people's party demanded changes in electoral law leading to the introduction of single member districts, with which they had had experience before 1914 and they knew how to conduct electoral campaign (Cimek, 2005, p. 33). The new project was heavily criticised by people connected with the circles around Regency Council, who before November 1918 prepared new projects of electoral law of the Kingdom of Poland (which was founded on the basis of Act of 5 th November) to the order of Regency Council itself. Prof. Józef Siemieński paid attention to serious differences in the size of electoral districts and in the number of mandates to be taken, since in small districts it was necessary to get around $30 \%$ of votes, whereas in bigger districts to become an MP, one had to acquire less than $10 \%$ of votes.

The technique used to conduct the elections involved a serious threat to the idea of proportionality: if there was only one voting list or many lists but with the number of candidates equaling the number of seats to be taken, the elections were not carried out. It leads to the conclusion that votes were distributed proportionally on the level of an electoral district, without the use of Czechoslovakian system of state list, since in that case a problem of dealing with districts in which elections were not held would occur. Thus, Polish electoral law seemed similar to the regulations used in Romanian Transylvania in 1919 and 1920.

According to some experts of that time, the proposed proportional system could be introduced only in a state with fully developed party system and established democracy, which could not have been said about Poland of that time, since almost all institutions connected with public life were only staring their activity on state level (llski, 2014). Because of that, the decision of Head of the State to introduce the electoral law in question may be a sign of heavily critised by him party politics.

When it comes to the voting method itself, it should be stressed that closed lists were used at that time, with the voter was only to underline the number of voting list he wanted to support. It involved getting to know the lists of candidates in advance. Distribution of numbers of voting lists was performed according to the order of declaring them to the election committee

1 According to J. Buzek, list blocking was possible only in electoral districts not homogeneous ethnically, but it should be forbidden in ethnically homogeneous ones. Buzek claimed that in countries consistent ethnically, like Germany or Austria, the experiment of blocking the lists was allowed in "opening elections" only, whereas in the following elections it was out of the question. 
(Dziennik Praw, 18/1918, art. 45). What is interesting is that the possibility to stand as a candidate for elections in many electoral districts, known before Great War, was still practiced. It demanded further declaration which electoral district one wanted to represent and the next person from the list replacing the first one.

Nowadays, the obligation to buy a voting card by a person who wanted to make use of their voting right can be considered controversial. The price of the voting card was 5 Polish fenigs or 10 hellers in Galicia. Electoral law established some precautions against the attempts to rig the elections. A voting card bought had to be put into an envelope that was to be stamped in a polling station (Dziennik Praw, 18/1918, art. 70). Voting cards without envelops were considered not valid. Privateness of the elections was also secured - every citizen could fill out the card at home.

Finally, the elections were conducted only some part of Poland, and in hostilities areas (in Galicia especially), MPs representing those regions in the lower House of Austrian Parliament in 1918, were appointed as additional MPs.

The most intriguing situation took place in Lwow, where two seats were vacant because of the death of two MPs. A decree of the Head of the State ordered to fill them upon elections which were to be conducted on the basis of old Austrian electoral law of 1907, not on new Polish one (Dziennik Praw, 18/1918, art. 47). It was the only example of the use of Austrian regulations in successor states to such an extent.

Summing up, the adoption of proportional electoral system by reborn Poland was a way of leaving the well-known plurality voting systems that had been known and used for most electoral acts in the annexed lands before World War I1. It was surely triggered by the eagerness to dissociate from the tradition of foreign states but it was also connected with the European trend to use proportional electoral law.

To sum up, Austrian electoral law was a breakthrough since it introduced the idea of equal and general voting. It also set democratic standards on the area where it used to be valid in the years 1907-1918.

Successor states, en bloc, decided not to keep it after 1918, which can be attributed to several factors. First of all, it may have been triggered by ambition to dissociate from the criticised Habsburg state. It can be ascribed to Poland, where people's party, during a debate over the first electoral law, demanded the introduction of rules taken from Austrian regulations, which was opposed by the socialists.

Secondly, the introduction of plurality voting system on regions not homogeneous ethnically would be politically dangerous since it transferred electoral competition from political to ethnic matters, which was not welcome in view of the need to consolidate democracy in new states.

A controversial thesis can be given that the 1907 regulations could not have been hold because of a completely different political situation in successor states. in 1907 it was all about relieving the social tension; after 1918, in newly created states especially, the consolidation of the country, with the use of proportional elections, was the most important. Proportional elections made fair distribution of seats, without the discrimination of particular ethnic minority groups, possible. It was of upmost importance to build a positive picture of a new political entity on international level.

It should be stressed that Beck's electoral reform set political minimum that could not be crossed by any country. It should also be reminded that some solutions that had been functioning since 1907 were later adopted by the successor states, especially in terms of order regulations, or so called incomaptibilitas. Austrian law can be called vital for further functioning of democracy in the successor states.

Austrian regulations of 1907 were valid the longest in Bucovina, where they were used for the last time during 1922 elections. It should be reminded that there was an incident of acting upon Austrian regulations during elections in 1919 in the Polish city of Lwow.

\section{References}

[1] Buszko J. (1956). Sejmowa reforma wyborcza w Galicji 1905-1914, Warszawa: PWN.

[2] Buzek J. (1922). Ordynacja wyborcza do Sejmu i Senatu, Warszawa-Lwów: Książnica Polskiego Tow. Naucz. Szkół Wyższych.

1 When it comes to Prussian Partition, majority and general regulations functioned in case of the Parliament for all of Germany. Till the end of existence of German Empire, Prussian Parliament was elected due to class electoral law. 
[3] Cimek H. (2005), Ludowcy wobec idei parlamentu polskiego w latach 1918-1919, „Polityka i społeczeństwo”, 2/2005, 27-35.

[4] Dubicki A. (2013). System partyjny Królestwa Rumunii. Uwarunkowania i funkcjonowanie, Łódź: Wydawnictwo Ut.

[5] Dziennik Praw, 18/1918.

[6] Ilski Z. (2014), Ordynacja wyborcza u progu Niepodległej Polski, http://bazowy.nazwa.pl/jow.pl/jow/index.php?option=com_content\&task=view\&id=330\&ltemid=96\&limit=1\&limit start=4 [16 VI 2014].

[7] Mamina I. (2000), Monarhia constituțională în România. Enciclopedie politică 1866-1938, București: Editura Enciclopedică.

[8] Radu S. (2005), Modernizarea sistemului electoral din România (1866-1937), laşi: Institutul European.

[9] Starzyński S. (1907). Studya konstytucyjne, vol. 1. Różne projekty reformy prawa wyborczego, Lwów: B. Połomiecki.

[10] Starzyński S. (1907a). Nowa ustawa wyborcza, „Przegląd Prawa i Administracji. Rozprawy i zapiski literackie”, XXXII, 1907, 287-300, 433-450.

[11] Starzyński S. (2010), Współczesny ustrój prawno-polityczny Polski i innych państw słowiańskich, Warszawa: Wydawnictwo Sejmowe.

[12] Tomaszewski J. (2006). Czechy i Słowacja, Warszawa: Wydawnictwo Trio.

[13] Watt R. M. (2005). Gorzka chwała. Polska i jej los 1918-1939. Warszawa: A.M.E Plus Group Sp. z 0.0. 